\title{
Ergot alkaloid intoxication in perennial ryegrass (Lolium perenne): an emerging animal health concern in Ireland?
}

Mary J Canty ${ }^{1,2^{*}}$, Ursula Fogarty ${ }^{3}$, Michael K Sheridan ${ }^{2}$, Steve M Ensley ${ }^{4}$, Dwayne E Schrunk ${ }^{4}$ and Simon J More ${ }^{1}$

\begin{abstract}
Four primary mycotoxicosis have been reported in livestock caused by fungal infections of grasses or cereals by members of the Clavicipitaceae family. Ergotism (generally associated with grasses, rye, triticale and other grains) and fescue toxicosis (associated with tall fescue grass, Festuca arundinacea) are both caused by ergot alkaloids, and referred to as 'ergot alkaloid intoxication'. Ryegrass staggers (associated with perennial ryegrass Lolium perenne) is due to intoxication with an indole-diperpene, Lolitrem B, and metabolites. Fescue-associated oedema, recently described in Australia, may be associated with a pyrrolizidine alkaloid, $\mathrm{N}$-acetyl norloline.

Ergotism, caused by the fungus Claviceps purpurea, is visible and infects the outside of the plant seed. Fescue toxicosis and ryegrass staggers are caused by Neotyphodium coenophalium and N. Iolii, respectively. Fescue-associated oedema has been associated with tall fescue varieties infected with a specific strain of N. coenophialum (AR542, Max P or Max Q). The name Neotyphodium refers to asexual derivatives of Epichloë spp., which have collectively been termed the epichloë fungi. These fungi exist symbiotically within the grass and are invisible to the naked eye.

The primary toxicological effect of ergot alkaloid involves vasoconstriction and/or hypoprolactinaemia. Ingestion of ergot alkaloid by livestock can cause a range of effects, including poor weight gain, reduced fertility, hyperthermia, convulsions, gangrene of the extremities, and death. To date there are no published reports, either internationally or nationally, reporting ergot alkaloid intoxication specifically associated with perennial ryegrass endophytes. However, unpublished reports from the Irish Equine Centre have identified a potential emerging problem of ergot alkaloid intoxication with respect to equines and bovines, on primarily perennial ryegrass-based diets. Ergovaline has been isolated in varying concentrations in the herbage of a small number of equine and bovine farms where poor animal health and performance had been reported. Additionally, in some circumstances changes to the diet, where animals were fed primarily herbage, were sufficient to reverse adverse effects. Pending additional information, these results suggest that Irish farm advisors and veterinarians should be aware of the potential adverse role on animal health and performance of ergot alkaloids from perennial ryegrass infected with endophytic fungi.
\end{abstract}

Keywords: Ergot alkaloids, Intoxication, Perennial ryegrass, Animal health, Ireland

\section{Introduction}

\section{Mycotoxicosis associated with grasses and cereals}

Four primary mycotoxicosis in livestock associated with fungal infections of grasses or cereals by members of the Clavicipitaceae family have been reported in the international literature (Table 1), including:

\footnotetext{
* Correspondence: mary.canty@agriculture.gov.ie

${ }^{1}$ Centre for Veterinary Epidemiology and Risk Analysis (CVERA), Veterinary Sciences Centre, University College Dublin, Belfield, Dublin 4, Ireland ${ }^{2}$ Department of Agriculture, Food and the Marine, Agriculture House, Kildare St, Dublin 2, Ireland

Full list of author information is available at the end of the article
}

- Ergotism, principally associated with ergotamine, which is an ergot alkaloid toxin produced by the external fungus Claviceps purpurea typically found on the seed heads in grass, rye and other cereals;

- Fescue toxicosis (including fescue foot), principally associated with ergovaline, the ergot alkaloid toxin produced by the internal (or endophyte) fungus Neotyphodium (previously Acremonium) coenophialum found in tall fescue (Festuca arundinacea) grass;

\section{Biomed Central}

(C) 2014 Canty et al.; licensee BioMed Central Ltd. This is an Open Access article distributed under the terms of the Creative Commons Attribution License (http://creativecommons.org/licenses/by/2.0), which permits unrestricted use, distribution, and reproduction in any medium, provided the original work is properly credited. 
- Ryegrass staggers, principally associated with Lolitrem B, an indole-diterpene toxin (not an ergot alkaloid toxin), and metabolites produced by the endophyte fungus $N$. lolii found in perennial ryegrass (Lolium perenne); and

- Fescue-associated oedema, recently described in Australia in horses grazing pastures of tall fescue (F. arundinacea) carrying a specific strain of $N$. coenophialum (AR542; Max P or Max Q) that does not produce ergovaline. A pyrrolizine alkaloid, $\mathrm{N}$-acetyl norloline, may be responsible [1].

Mycotoxicosis from grasses and cereals is a recognized animal health issue (Table 1). For example, there are numerous reports of fescue toxicosis from the USA [4,5], New Zealand [6-8] and Australia [1,6]. After taking account of impact on equines and on both small and large ruminants, it is estimated that the combined losses due to ergot alkaloid intoxication of animal feed in the USA are likely to exceed $\$ 1$ billion annually [9]. In Europe, intoxications of livestock with ergot toxins has largely been associated with cereals [10]. There have been reports of ergot poisoning in both Ireland and England due to Claviceps purpura [11,12]. Lameness and mycotoxicoses are difficult to differentiate from diseases with similar epidemiological, clinical, clinicopathological and histopathological profiles, noting that the fungal agent may be invisible to the eye, for example $N$. coenophalium [2], and generally relies on evaluation of a representative sample of the suspect feed(s) consumed by the livestock.
The name Neotyphodium refers to asexual derivatives of Epichloë spp., which have collectively been termed the epichloë fungi [13] or Epichloë/Neotyphodium spp. [14]. A change in nomenclature, to align these two families, has recently been proposed [15]. They are symbiotic fungi (endophytes) that grow within cool season grasses, in an apparent co-evolutionary relationship [14]. Neotyphodium spp. are invisible to the naked eye (Figure 1). In contrast, C. purpurea is externally visible on the plant and seeds (Figure 2) and therefore easier to associate with clinical signs in affected grazing livestock. These fungi are all members of the same fungal family, Clavicipitaceae. Within this fungal family, the fungi are divided into those that reproduce sexually, including C. purpurea and Epichloë spp., and those that are asexual (e.g. N. coenophialum and N. lolii). Epichloë spp. can reproduce sexually by forming stromata, whereas Neotyphodium endophytes are always transmitted by hyphae growing into the developing seeds of maternal host plants [16].

Grasses naturally cohabitate with numerous microorganisms including fungal endophytes, which are important to the ecological fitness and species diversity of the grass. The fungal endophytes benefit from inhabiting the grass's interior because this is a protected area, with little competition from other microorganisms, and a reliable source of nutrition [17]. In turn, endophyte infection confers several ecological benefits to infected plants, including resistance to invertebrate and vertebrate herbivory. It may also facilitate enhanced growth, mineral uptake and resistance to drought [17-20], thereby acting as a biocontrol agent resulting in improved plant persistence [21].

Table 1 Mycotoxicoses in cattle and horses associated with fungal infections of grasses or cereals by members of the Clavicipitaceae family, based on data from Radostits [2] and Mostrom and Jacobson [3]

\begin{tabular}{|c|c|c|c|}
\hline $\begin{array}{l}\text { Fungus } \\
\text { [Grass \& cereal] }\end{array}$ & Mycotoxin & Disease & Clinical signs and pathogenesis \\
\hline $\begin{array}{l}\text { Neotyphodium lolii } \\
\text { [Perennial ryegrass } \\
\text { (Lolium perennae)] }\end{array}$ & $\begin{array}{l}\text { Lolitrems (Lolitrem B), an } \\
\text { indole-diterpene toxin }\end{array}$ & Ryegrass staggers & $\begin{array}{l}\text { When disturbed gross incoordination, falling hypersensitivity. } \\
\text { Functional derangement of nervous tissue function. No } \\
\text { histological lesions }\end{array}$ \\
\hline $\begin{array}{l}\text { Neotyphodium } \\
\text { coenophialum }\end{array}$ & \multirow[t]{3}{*}{ Ergovaline, an ergot alkaloid } & Fescue toxicosis & $\begin{array}{l}\text { Low milk yield or weight gain, hypersalivation, seek shade. } \\
\text { Depression of blood prolactin concentrations }\end{array}$ \\
\hline $\begin{array}{l}\text { [Tall fescue } \\
\text { (Festuca arundinaceae)] }\end{array}$ & & Fescue foot & $\begin{array}{l}\text { Loss of tail switch, distal limbs, tail tip gangrene. Local } \\
\text { vasoconstriction restricts blood supply }\end{array}$ \\
\hline $\begin{array}{l}\text { [Perennial ryegrass } \\
\text { (Lolium perennae)] }\end{array}$ & & Prolonged gestation & $\begin{array}{l}\text { Long gestation, dystocia, abortion, stillbirth, agalactia. } \\
\text { Vasoconstriction cause placental edema, reducing circulating } \\
\text { prolactin }\end{array}$ \\
\hline Claviceps purpurea & \multirow{2}{*}{$\begin{array}{l}\text { A range of ergot alkaloids, } \\
\text { principally ergotamine, but also } \\
\text { ergocristine, ergosine, ergocorine } \\
\text { and ergocryptine }\end{array}$} & Ergotism & $\begin{array}{l}\text { Lameness, gangrene of lower limbs, ear tips, loss of tail switch. } \\
\text { Arteriolar spasm causes deficient blood supply body parts }\end{array}$ \\
\hline $\begin{array}{l}\text { [Cereals, rye, triticale, } \\
\text { grains, grasses] }\end{array}$ & & Hyperthermia & $\begin{array}{l}\text { Hyperthermia, salivation, dyspnea. Reduced blood supply to } \\
\text { skin reduces heat loss }\end{array}$ \\
\hline
\end{tabular}




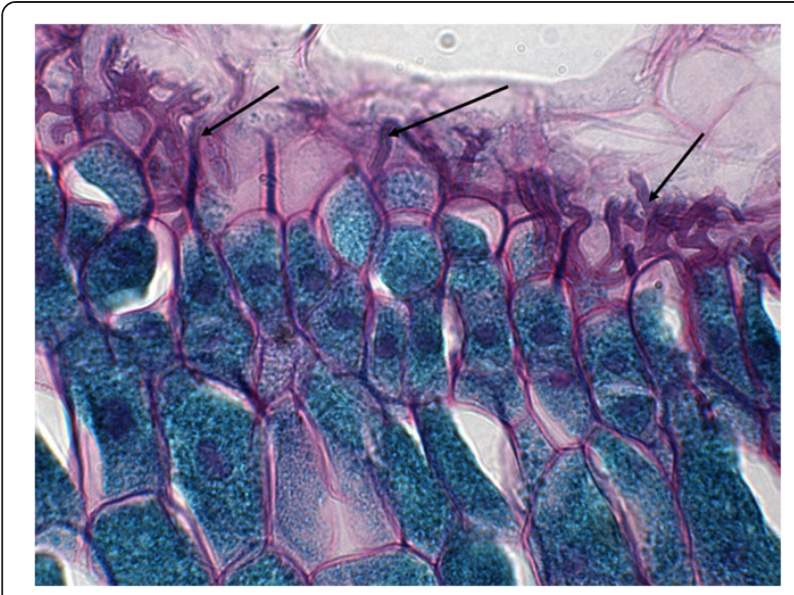

Figure 1 Perennial ryegrass infected with endophytes, as indicated by the black arrows. Periodic acid-Schiff stained $3 \mu \mathrm{m}$ section, 1000× oil immersion.

This article focuses on ergot alkaloid intoxication in farmed animals, with two objectives. Firstly, we present current knowledge based on a review of the international scientific literature. Secondly, we summarise data that are currently available in Ireland, highlighting knowledge gaps and presenting recommendations.

\section{Review}

\section{Ergot alkaloids}

Ergot alkaloids are complex compounds produced by certain fungi. They are secondary metabolites most of which have been isolated from fungal species belonging to the family of Clavicipitaceae. They include C. purpurea, which occurs predominantly on rye, wheat and barley, and Neotyphodium species, which infect forages and turf grasses, including perennial rye grass and tall fescue (F. arundinacea) $[10,22]$, and cereals. The common structural feature of natural ergot alkaloid is the ergoline ring methylated on nitrogen N-6 and variously substituted on C-8 [23,24]. Depending on the substitution on $\mathrm{C}-8$, ergot alkaloids are classified into four groups: clavines, lysergic acid, simple lysergic acid amides, and ergopeptines [23]. In this review, with a focus on the causes of ergotism and fescue toxicosis, it is primarily the ergopeptines that are of interest. This is a complex area, noting the considerable variation that is present both between and even within Neotyphodium species with respect to the alkaloids produced [14]. Further, different ergot alkaloids have different biological activities. $N$. coenophialum alone produces over 30 ergot alkaloids, including 17 that affect livestock. Nonetheless, ergovaline is the primary ergopeptide produced by the Neotyphodium spp. $[19,25]$ and the principal toxin associated with the different forms of fescue toxicosis. Ergovaline is thought to be the most physiologically active ergot alkaloid produced by $N$. coenophialum [22]. It has been demonstrated that

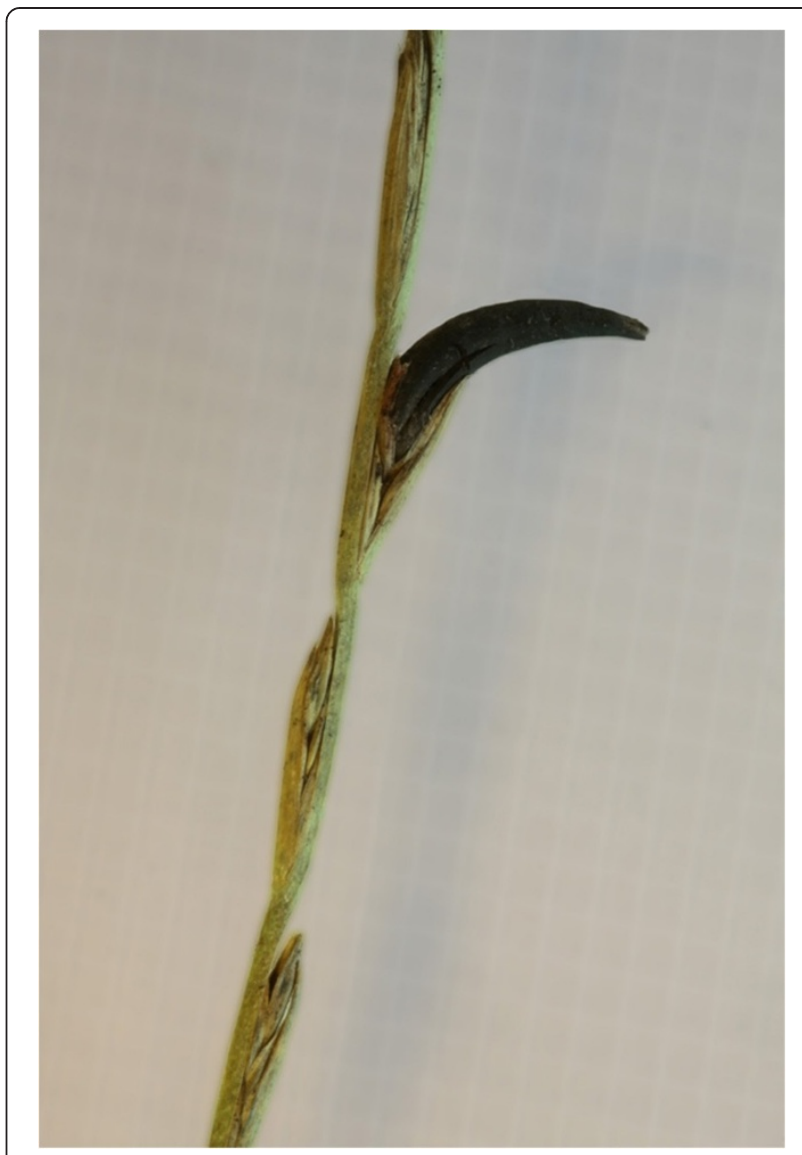

Figure 2 Externally visible parasitic fungus Claviceps purpurea on the plant/seed.

ergovaline is approximately 1,000 times more potent and 5 times more efficacious in causing vasoconstriction than lysergic acid [26,27]. Similarly, C. purpurea produces many ergopeptides, the most prominent toxins amongst them being ergotamine, ergocristine, ergosine, ergocryptine and ergocornine [22,24].

Although there are differences in the primary ergopeptide produced by Neotyphodium spp. and C. purpurea, the mode of action of these ergopeptides is similar and the clinical presentation of toxicity in animals can be indistinguishable. Any clinical differences between fescue toxicosis and ergotism, if observed, is likely to be due to the higher ergopeptine alkaloid concentrations in ergot $(C$. purpurea) compared with fescue endophytes, and the tendency for a longer duration of exposure to fescue endophytes [28]. In the scientific literature, fescue toxicosis and ergotism are frequently considered as distinct intoxications, reflecting differences in fungal sources. However, both are the consequences of the adverse effects of ergot alkaloids, and have been collectively referred to as 'ergot alkaloid intoxication' [3]. 


\section{Mode of action of ergot alkaloids}

The biological activity of the ergot alkaloids in animal systems is largely due to the similarity of the ergoline ring structure to biogenic amines such as serotonin, dopamine, noradrenaline, and adrenaline. The structural similarity allows many of the ergot alkaloids to bind biogenic amine receptors and to elicit such effects as decreased serum prolactin and vasoconstriction [9]. The primary pharmaceutical actions of ergot alkaloid, whether of endophytic or ergot origin, involves vasoconstriction and/or hypoprolactinaemia. Vasoconstriction is association with $\mathrm{D}_{1}$-dopaminergic receptor inhibition and partial agonism of the $\alpha_{1}$-adrenergic and serotonin receptors. Hypoprolactinaemia results from the stimulation of lactotrophic $\mathrm{D}_{2}$-dopamine receptors in the anterior pituitary and inhibition of probating secretion. In ruminants, vasoconstrictive effects predominate and cause gangrenous and hyperthermic forms of ergot alkaloid intoxication, with the gangrenous syndrome generally occurring in low environmental temperatures. It results in diminished blood flow to the extremities, lameness and eventually dry gangrene. Prolactin plays a diverse role in lactogenesis, steroidogenesis and various reproductive pathways, and the reproductive form of ergot alkaloid intoxication is characterized by decreased milk production, abnormal progestagen metabolism, delayed parturition, and other reproductive abnormalities, including subfertility. Horses are more susceptible to reproductive effects than ruminants, as ruminants produce a placental lactogen during pregnancy [28].

Ergot alkaloid intoxication results in disruption of several physiological systems, relating to reproduction, growth, cardiovascular function, and the signs of these disruptions vary with severity. Ruminant livestock are generally less affected than non-ruminants and hindgut fibre digesting livestock [9]. Susceptibility of livestock to ergotism seems to vary with species, breed, age, gender, and physiologic state [3], with other stressors and management practices also playing a contributory role in the pathogenesis of impaired reproductive function. There is some evidence that ergopeptines, including ergovaline, bio-accumulate in body fat/lipid stores. However, very little is known about the distribution of ergot alkaloids in the tissue of grazing livestock. This lack of knowledge may in part be due to technical constraints in the sensitivity and selectivity of the analytical methods available for the detection of these alkaloids generally [9].

\section{Animal performance and ergot alkaloids}

The effects of ingestion of ergot alkaloid will vary substantially in accordance with the fungal source and the level of infestation within the grass or cereal. Ingestion of ergot alkaloid by livestock can cause a range of effects from reduced performance to acute clinical signs.
These include poor weight gain, reduced fertility, hyperthermia, convulsions, gangrene of the extremities, and death $[3,28]$. Further, reduced feed intake, dry matter digestibility, nitrogen retention, average daily gain, serum prolactin and elevated rectal temperatures $[29,30]$ and reduced growth and prolactin in heifers $[4,5]$ have been reported in steers and heifers, respectively, that were fed endophyte-infected tall fescue. In relatively cool temperatures, Holstein cows fed a total mixed ration with fescue hay containing either low $(45 \mu \mathrm{g} / \mathrm{kg} \mathrm{DM})$ or high $(782 \mu \mathrm{g} / \mathrm{kg} \mathrm{DM})$ concentrations of ergovaline showed similar intake and milk yields, but milk fat and milk protein were reduced in the high ergovaline diet [31]. Conversely, a 4.6 L reduction in milk production of Holstein-Friesian cows was associated with high concentrations of ergovaline in ryegrass silage (total silage ergovaline concentrations of $1.78 \mu \mathrm{g} / \mathrm{g}$ ) [7]. Cows also had elevated milk somatic cell counts and reduced reproductive performance. It has been proposed that cows under metabolic stress during the transition period (from drying off through to early lactation) may be more sensitive to the effects of feed contaminated with mycotoxin, amongst other things [32]. No adverse effect on pregnancy rate and embryonic loss were reported in beef cows that were grazing endophyte-infected tall fescue [33]. However, it was reported that less oestrous activity was observed following synchronization treatment in weanling heifers grazing high endophyte pastures [4]. Progesterone concentrations in these heifers suggested a higher incidence of luteal dysfunction. Despite this, pregnancy rates were similar to heifers fed low endophyteinfected tall fescue.

Reproductive disorders arising from exposure to ergot alkaloids are more common and more dramatic in horses than ruminants, and particularly among lategestational and early post-parturient mares [22]. These disorders include failure to come into heat, early-term abortions, prolonged pregnancies, dystocia, retained placentas, poor udder development with little or no milk production, and poor foal survival. Mares removed from endophyte-infected pastures one month prior to foaling usually recover and have normal foals, however, milk production may be decreased [19]. The effect on stallions is less pronounced. A preliminary study of breeding stallions given feed containing infected fescue seed showed that sperm motility, number morphology and sperm morphology were not different when compared with control animals [34]. Similarly, a study in ram lambs fed endophyte-infected fescue seed (34\% of the diet, $4.8 \mu \mathrm{g} / \mathrm{g}$ ergovaline) showed that scrotal temperature, scrotal circumference, semen volume, percent sperm motility, and percent normal sperm were not different compared with control rams [35]. 
Table 2 Cases of suspected ergot poisoning in cattle in Ireland, from spring 1986 [9]

\begin{tabular}{lll}
\hline Animal species & Presentation & Notes \\
\hline $\begin{array}{l}\text { 21/2year old } \\
\text { Friesian heifer }\end{array}$ & $\begin{array}{l}\text { Very dull and inappetant, obvious pinging on auscultation and percussion of the left } \\
\text { paralumbar fossa associated with a large empty rumen, marked ketonuria }\end{array}$ & $\begin{array}{l}\text { Fed mouldy concentrates, aborted } \\
\text { at } 8 \text { months gestation }\end{array}$ \\
$\begin{array}{l}5 \text { year old } \\
\text { Jersey cow }\end{array}$ & Recumbent, in extremis & Silage fed \\
$\begin{array}{l}1 \text { year old } \\
\text { Friesian bullock }\end{array}$ & Quite bright, eating normally & Silage fed \\
3 month old & Quite bright, eating normally & Fed poor quality hay \\
Friesian calf & & \\
\hline
\end{tabular}

All four animals were negative on both serology and bacteriology to Salmonella spp. All animals presented with cold insensitive extremities, and with some degree of sloughing of the ear tips, tail and digital horn of the hind limbs.

\section{Threshold concentrations for ergot alkaloid affecting animal health}

Diagnostic testing for ergot alkaloid intoxication (fescue toxicosis and ergotism) includes the use of high performance liquid chromatography (HPLC) to determine the concentrations of ergovaline, ergotamine, ergocristine, ergosine, ergocornine and ergocryptine in forages and/or grains. Adverse effects on livestock performance are typically observed when total dietary ergopeptine alkaloids exceed 100 to 200 parts per billion (ppb) [3,28]. Fescue toxicosis generally represents the effects of sub-acute to chronic exposures to 200 to $600 \mathrm{ppb}$ of ergovaline commonly found in fescue grass pastures infected with endophytes [28]. Concentrations of $150 \mathrm{ppb}$ were associated with reduced growth in lambs, and fescue toxicosis in heat-stressed steers was reported when ergovaline concentrations were approximately $200 \mathrm{ppb}$ in the total feed [36].
Oregon State University researchers have reported higher dietary ergovaline thresholds concentrations, specifically related to the induction of clinical disease, in horses (300 to $500 \mathrm{ppb}$ ), cattle (400 to $750 \mathrm{ppb}$ ) and sheep (500 to $800 \mathrm{ppb}$ ) [19]. However, agalactia and clinical fescue toxicosis has also been reported in mares that were fed total dietary concentrations of ergovaline as low as $50 \mathrm{ppb}$ and $100 \mathrm{ppb}$, respectively [36]. Mares $(\mathrm{n}=4)$ grazing endophyte-infected fescue pasture, with relatively low serum ergovaline concentrations between 0.7 to $3.8 \mathrm{pg} / \mathrm{ml}$ (the concentration of other ergot alkaloids was not reported), displayed clinical signs of ergot alkaloid reproductive toxicity including agalactia, prolonged gestation, placental thickening, mare and neonatal mortality [37]. Ergovaline concentrations may vary within and between different fields of the same grass variety, even with the same level of infection, at different times of the year and in

Table 3 Ergot alkaloid in herbage from Ireland (unpublished reports from the Irish Equine Centre, samples were submitted to either the veterinary diagnostic laboratory, lowa State University, USA or the veterinary medicine diagnostic laboratory, University of Missouri Veterinary Medicine, USA, for determination of ergovaline by HPLC)

\begin{tabular}{|c|c|c|c|}
\hline Plant samples & Date, number & $\begin{array}{l}\text { Ergovaline concentration } \\
(\mathrm{ppb})\end{array}$ & Notes \\
\hline \multirow[t]{2}{*}{$\begin{array}{l}\text { Herbage samples from } \\
\text { perennial ryegrass (Lolium } \\
\text { perenne)-rich pastures }\end{array}$} & $\begin{array}{l}\text { April 2007, } n=39 \text { (including } 5 \\
\text { pooled samples) }\end{array}$ & $\begin{array}{l}10-210 \text { (for } 17 \text { samples, all } \\
\text { other samples were below } \\
\text { the limit of detection) }\end{array}$ & \multirow{2}{*}{$\begin{array}{l}\text { Collected from a cattle farm in Co. Kilkenny, with } \\
\text { long-term problems of poor performance, and from } \\
\text { the wider area at two distinct time points as part of a } \\
\text { trace element survey [40] }\end{array}$} \\
\hline & $\begin{array}{l}\text { September 2007, } \\
\mathrm{n}=25 \text { (including } 5 \text { pooled samples) }\end{array}$ & $\begin{array}{l}20-75 \text { (for } 8 \text { samples, all } \\
\text { other samples were below } \\
\text { the limit of detection) }\end{array}$ & \\
\hline Herbage & $\begin{array}{l}\text { May-October 2010, grass }(n=12) \\
\text { and haylage }(n=3)\end{array}$ & $<25-300$ & $\begin{array}{l}\text { Collected on } 13 \text { stud farms in counties Kildare, } \\
\text { Kilkenny and Cork where veterinary surgeons } \\
\text { reported high incidences of infertility, endometrial } \\
\text { oedema, red bag presentations, post partum } \\
\text { hemorrhage in mares, rotaviruses outbreaks in } 2 \text { to } \\
3 \text { month old foals at grass, and distal leg oedema in } \\
\text { yearlings. Some conditions were reported to be } \\
\text { responsive to changes in herbage or topping of } \\
\text { ergotised seed heads }\end{array}$ \\
\hline Perennial ryegrass seed & May-June 2010, $n=8$ & $<25-760$ & \multirow[t]{4}{*}{ Seed from commercial suppliers } \\
\hline $\begin{array}{l}\text { Perennial ryegrass/clover } \\
\text { seed mixes }\end{array}$ & May-June 2010, n= 3 & $<25,100$ and 1420 & \\
\hline Fescue grass seed mix & May-June 2010, n= 1 & 900 & \\
\hline Timothy grass seed & May-June 2010, n=2 & $<25$ & \\
\hline
\end{tabular}


different years. It is important to note that increasing levels of nitrogen fertilizer on pasture can lead to an increase in ergovaline concentrations, as ergovaline is produced when plants are growing under stress [19].

\section{Ergot alkaloids in Ireland}

Little data are currently available about ergot alkaloid in Ireland, with reports currently confined to ergotism caused by Claviceps purpura. This may be explained, at least in part, by the recognised association between ergot alkaloid intoxication and tall fescue (F. arundinacea) grasses, which are much less common in Irish pastures than in pastures in other parts of the world. In Ireland, there is a predominance of perennial rye grass, Italian ryegrass (L. multiflorum) and white clover (Trifolium repens), with perennial rye grass alone accounting for $95 \%$ of the forage grass seed sales in Ireland [38]. Neotyphodium species were identified in 11 of 28 wild seed populations of perennial ryegrass collected in Ireland [39] during 1981, however, the species of the endophytic fungus was uncertain.

Case reports from Ireland, with suspected ergot alkaloid involvement, are presented in Table 2, and available evidence of ergot alkaloid in herbage in Ireland in Table 3. Herbage ergovaline concentrations reported in Irish samples are not dissimilar to concentrations that are associated with adverse sub-clinical effects on livestock performance in North America [3,29]. In some of the seed samples analysed, ergovaline concentrations may have been sufficient to induce clinical ergot alkaloid intoxication.

\section{Conclusions}

Given that ergovaline, typically associated with tall fescue grasses has been reported in perennial ryegrass in Ireland, and was associated with poor performance in animals, there may be a need to:

- Confirm the fungal source of the ergot alkaloids so far identified in Ireland;

- Undertake epidemiological investigations to determine the temporal and spatial distribution of ergot alkaloid intoxication of Irish perennial ryegrass;

- Develop a coordinated national sampling, testing and reporting system for ergot alkaloid in forages and feeds; and

- Consider the need for inclusion of ergot alkaloid testing within the EU seed certification regulatory framework.

Pending additional information, these results suggest that Irish farm advisors and veterinarians should be cognisant of the potential adverse role that ergot alkaloid from infected pasture grass can have on animal health and performance.

\section{Competing interests}

The authors declare they have no competing interests.

\section{Authors' contributions}

MJC, UF, MKS and SJM conceived the review and participated in its design. MJC prepared the manuscript, with considerable input from UF, MKS and SJM. All authors read and approved the final manuscript.

\section{Acknowledgements}

We thank John Stafford, Greyabbey Veterinary Hospital, Kildare, Ireland for the provision of the ergot body sample, and Brian Cloak, Veterinary Pathology, UCD Veterinary Sciences Centre, Belfield, Dublin 4, Ireland, for processing images. We also gratefully acknowledge helpful advice from Chris Bourke, Scott Laidlaw and George Rottinghaus.

\section{Author details}

${ }^{1}$ Centre for Veterinary Epidemiology and Risk Analysis (CVERA), Veterinary Sciences Centre, University College Dublin, Belfield, Dublin 4, Ireland.

${ }^{2}$ Department of Agriculture, Food and the Marine, Agriculture House, Kildare St, Dublin 2, Ireland. ${ }^{3}$ Irish Equine Centre, Johnstown, Naas, Co. Kildare, Ireland. ${ }^{4}$ College of Veterinary Medicine, lowa State University, Ames, IA 2011, USA.

Received: 21 January 2013 Accepted: 6 August 2014

Published: 25 September 2014

\section{References}

1. Bourke CA, Hunt E, Watson R: Fescue-associated oedema of horses grazing on endophyte-inoculated tall fescue grass (Festuca arundinacea) pastures. Aust Vet J 2009, 87:492-498.

2. Radostits OM, Gay CC, Hinchcliff KW, Constable PD: Veterinary Medicine: A textbook of the diseases of cattle, horses, sheep, pigs and goats. 10th edition. New York: Elsevier; 2007.

3. Mostrom MS, Jacobsen BJ: Ruminant mycotoxicosis. Vet Clin North Am Food Anim Pract 2011, 27:315-344.

4. Mahmood T, Ott RS, Foley GL, Zinn GM, Schaeffer DJ, Kesler DJ: Growth and ovarian function of weanling and yearling beef heifer grazing endophyteinfected tall fescue pastures. Theriogenology 1994, 42:1149-1158.

5. Drewnoski ME, Oliphant EJ, Poore MH, Green JT, Hockett ME: Growth and reproductive performance of beef heifers grazing endophyte-free, endophyte-infected and novel endophyte-infected tall fescue. Livest Sci 2009, 128:254-260.

6. Easton HS, Lee CK, Fitzgerald RD: Tall fescue in Australia and New Zealand. New Zeal J Agr Res 1994, 37:405-417.

7. Lean IJ: Association between feeding perennial ryegrass (Lolium perenne cultivar Grasslands Impact) containing high concentrations of ergovaline, and health and productivity in a herd of lactating dairy cows. Aust Vet J 2001, 79:262-264.

8. Fletcher $L R$, Sutherland BL: Sheep responses to grazing ryegrass with AR37 endophyte. Proc New Zeal Grassland Assoc 2009, 71:127-132.

9. Strickland JR, Looper ML, Matthews JC, Rosenkrans Jnr CF, Flythe MD, Brown KR: Board-invited review: St. Anthony's Fire in livestock: causes, mechanisms, and potential solutions. J Anim Sci 2011, 89:1603-1626.

10. EFSA: Opinion of the scientific panel on contaminants in food chain on a request from the commission related to ergot as undesirable substance in animal feed. EFSA J 2005, 225:1-27.

11. Doherty ML, Murphy MG: Case report: suspected ergot poisoning in cattle. Ir Vet News 1986, 8:22-23.

12. Holliman A: Gangrenous ergotism in a suckler herd. Vet Rec 1989, 124:398-399.

13. Schardl CL, Leuchtmann A, Spiering MJ: Symbioses of grasses with seedborne fungal endophytes. Annu Rev Plant Biol 2004, 55:315-340.

14. Schardl CL, Florea S, Pan J, Nagabhyru P, Bec S, Calie PJ: The epichloae: alkaloid diversity and roles in symbiosis with grasses. Curr Opin Plant Biol 2013, 16:480-488.

15. Leuchtmann A, Bacon CW, Schardl CL, White JF, Tadych M: Nomenclatural realignment of Neotyphodium species with genus Epichloë. Mycologia 2014, 106:202-215.

16. Faeth SH, Sullivan TJ: Mutualistic asexual endophytes in native grass are usually parasitic. Am Nat 2003, 161:310-325. 
17. Kaldau G, Bacon C: Clavicipitaceous endophytes: their ability to enhance resistance of grasses to multiple stressors. Biol Control 2008, 46:57-71.

18. Clay K, Schardl CL: Evolutionary origins and ecological consequences of endophyte symbiosis with grasses. Am Nat 2002, 160:S99-S127.

19. Aldrich-Markham S, Pirelli G, Craig AM: Endophyte Toxins In Grass Seed Fields And Straw. Communicate. In Oregon State University Extension and Experiment Station Communications; 2003. EM 8598.

20. Latch GCM: Influence of Acremonium endophytes on perennial grass improvement. New Zeal J Agr Res 1994, 37:311-318.

21. Joost RE: Acremonium in fescue and ryegrass: boon or bane? a review. J Anim Sci 1995, 73:881-888.

22. Evans TJ: The endocrine disruptive effects of ergopeptine alkaloids on pregnant mares. Vet Clin North Am Equine Pract 2011, 27:165-173.

23. Flieger M, Wurst M, Shelby R: Ergot alkaloids - sources, structures and analytical methods. Folia Microbiol (Praha) 1997, 42:3-29.

24. Schardl CL, Panaccione DG, Tudzynski P: Ergot alkaloids - biology and molecular biology. Alkaloids Chem Biol 2006, 63:45-86.

25. Schardl CL, Young CA, Faulkner JR, Florea S, Pan J: Chemotrophic diversity of epichloae, fungal symbionts of grasses. Fungal Ecol 2012, 5:331-344.

26. Klotz JL, Bush LP, Smith DL, Schafer WD, Smith LL, Vevoda AO, Craig AM, Arrington BC, Strickland JR: Assessment of the vasoconstrictive potential of D-Lysergic acid using as isolated bovine lateral saphenous vein bioassay. J Anim Sci 2006, 84:3167-3175.

27. Klotz JL, Bush LP, Smith DL, Schafer WD, Smith LL, Arrington BC, Strickland JR: Ergovaline-induced vasoconstriction in an isolated bovine lateral saphenous vein bioassay. J Anim Sci 2007, 85:2330-2336.

28. Evans TJ: Diminished reproductive performance and selected toxicants in forages and grains. Vet Clin North Am Food Anim Pract 2011, 27:345-371.

29. Rice RL, Blodgett DJ, Schurig GG, Swecker WS, Fontenot JP, Allen VG, Akers RM: Evaluation of humoral immune response in cattle grazing endophyte-infected or endopyte-free fescue. Vet Immunol Immunopathol 1997, 59:285-291.

30. Matthews AK, Poore MH, Huntington BG, Green JT: Intake, digestion, and N metabolism in steers fed endophyte-free, ergot alkaloid-producing endophyte-infected, or nonergot alkaloid-producing endophyte-infected fescue hay. J Anim Sci 2005, 83:1179-1185.

31. Kim JH, Kim CW, Ahn GC, Park EK, Kim CM, Park KK: Ergovaline levels in tall fescue and its affect on performance of lactating cows. Anim Feed Sci Technol 2007, 136:330-337.

32. Fink-Gremmels $\mathrm{J}$ : The role of mycotoxins in the health and performance of dairy cows. Vet $J 2008,176: 84-92$

33. Burke JM, Rorie RW, Piper EL, Jackson WG: Reproductive responses to grazing endophyte-infected tall fescue. Theriogenology 2001, 56:357-369.

34. Fayrer-Hosken R, Heusner G, Hill N, Caudle A: Review on effects of fescue grass ergot alkaloids in the horse and preliminary study on effect of fescue grass ergot alkaloid in the stallion. J Equine Vet Sci 2008, 28:666-671.

35. Burke JM, Rosenkrans CF, Rorie RW, Golden C, Apple JK: Reproductive responses of ram lambs under short-term exposure to endophyteinfected tall fescue. Small Rumin Res 2006, 66:121-128.

36. Evans TJ, Rottinghaus GE, Casteel SW: Ergot. In Clinical Veterinary Toxicology. Edited by Plumlee KH. St. Louis: Mosby; 2004:234-250.

37. Lehner AF, Fitzgerald BP, Hughes CG, Tobin T, Camargo FC, May J, Dirikolu $L$, Christiansen DL, Ryan PL: Serum concentrations of ergovaline/ergot alkaloids in late-term pregnant mares grazing endophyte-infected tall fescue pastures: a preliminary report. Theriogenology 2008, 70:583.

38. Department of Agriculture Food and the Marine: Grass and Clover. Recommended List Varieties For Ireland 2012. http://www.agriculture.gov.ie/ media/migration/farmingsectors/crops/seedcertification/cropvariety evaluationcvepublications/2012/GrassCloverRecommendedList2012.pdf.
39. Lewis GC, Ravel C, Naffaa W, Astier C, Charmet G: Occurrence of Acremonium endophytes in wild populations of Lolium spp. in European countries and a relationship between level on infection and climate in France. Ann Appl Biol 1997, 130:227-238.

40. Canty MJ, McCormack S, Lane EA, Collins DM, More SJ: Essential elements and heavy metal concentrations in a small area of the Castlecomer Plateau, Co. Kilkenny, Ireland: Implications for animal performance. Irish J Agr Food Res 2011, 50:223-238.

doi:10.1186/2046-0481-67-21

Cite this article as: Canty et al:: Ergot alkaloid intoxication in perennial ryegrass (Lolium perenne): an emerging animal health concern in Ireland?. Irish Veterinary Journal 2014 67:21.

\section{Submit your next manuscript to BioMed Central and take full advantage of:}

- Convenient online submission

- Thorough peer review

- No space constraints or color figure charges

- Immediate publication on acceptance

- Inclusion in PubMed, CAS, Scopus and Google Scholar

- Research which is freely available for redistribution

Submit your manuscript at www.biomedcentral.com/submit
Ciomed Central 